\title{
Ocular features in Rubinstein-Taybi syndrome: investigation of 24 patients and review of the literature
}

\author{
Maria M van Genderen, Geert F Kinds, Frans C C Riemslag, Raoul C M Hennekam
}

\begin{abstract}
Aims-To delineate the nature and frequency of ocular pathology in RubinsteinTaybi syndrome (RTs).

Methods-Literature was searched for reports describing ocular symptoms in patients with RTs. 24 RTs patients (out of a total of 73 Dutch known RTs individuals) were selected for ophthalmological and electrophysiological examination, selection being based only on the distance between a patient's residence and the place of investigation.

Results-Most frequently reported eye anomalies in the literature were lacrimal duct obstruction, corneal abnormalities, congenital glaucoma, congenital cataract, and colobomata. Abnormalities of almost any eye segment have been published in case reports. Ophthalmological examination of 24 Dutch RTs patients showed a visual acuity $\leqslant 0.3$ in five patients. The most frequently found eye anomalies were nasolacrimal duct problems (six patients), cataract (six patients, four congenital), and retinal abnormalities (18 patients). VEPs showed an abnormal waveform in 15 patients. It was possible to perform an ERG in 18 patients, of whom 14 were abnormal (eight showed cone dysfunction, six cone-rod dysfunction).
\end{abstract}

Conclusions-Ocular abnormalities occur in the majority of RTs patients and can be remarkably diverse. The high frequency of retinal dysfunction $(78 \%)$ has not been described before. With age, retinal as well as electrophysiological abnormalities occur more frequently. In four patients no signs of retinal dysfunction were observed, indicating phenotypic heterogeneity. Further cytogenetic and molecular examination of the patients is needed before it becomes clear if this also represents genetic heterogeneity. Because of the high frequency of ocular abnormalities, visual function tests and electrophysiological investigations should be performed in every RTs patient at regular intervals.

(Br F Ophthalmol 2000;84:1177-1184)

Rubinstein-Taybi syndrome (RTs) is a well known mental retardation-multiple congenital anomalies syndrome, first described in 1957, but well delineated by Rubinstein and Taybi in $1963 .{ }^{1}$ The incidence has been estimated to be one in every 100000 newborns. ${ }^{2}$ Reports of more than 1000 pa- tients have been published worldwide. ${ }^{3}$ The syndrome is at least in part caused by microdeletions at chromosome $16 \mathrm{p} 13.3$ or by mutations in the gene for the CREB binding protein (CBP), which is located at $16 \mathrm{p} 13.3 . .^{5}$ As anomalies disturbing the amount of functional CBP are found in only $19 \%$ of patients, ${ }^{6}$ it remains possible that still other genes will also prove to be causative.

The major features of RTs are mental retardation, diminished growth, broad and sometimes medially deviated thumbs and big toes, and characteristic craniofacial abnormalities, consisting of microcephaly, downward slanted palpebral fissures, hypertelorism, long eyelashes, posteriorly rotated ears, beaked nose with the columella protruding well below the alae nasi, and pouting lower lip (see Fig 1). Data on ophthalmological findings are scarce. The number of patients reported in ophthalmological journals is small, and only a few were published in the last decade..$^{711}$ The only exception is the paper by Brei and co-workers, ${ }^{8}$ which provide a review of glaucoma and related conditions in RTs. However, all other ophthalmological features were not described, and no series of patients were personally investigated. This prompted us to perform a detailed ophthalmological examination of a group of well defined Dutch patients with RTs, and to compare the results with those from literature.

\section{Materials and methods}

LITERATURE REVIEW

The international literature was searched as completely as possible for reports describing ocular symptoms in patients with RTs. For reports before 1990, a bibliography was used ${ }^{12}$; for the more recent literature, a Medline search was performed. Most papers were dealing with symptoms in a single patient only, and most reviews paid only limited attention to ophthalmological features. Only reports describing patients in whom the diagnosis RTs was beyond doubt were included. In total, 373 publications describing features in one or more patients with RTs were available.

\section{PATIENTS}

In the Netherlands 73 patients with RTs are known (Hennekam RCM, unpublished data, 1999). Major non-ocular symptoms in 45 of the patients have been reported before ${ }^{2}$ and 13 others were tabulated elsewhere. ${ }^{13}$ These data were in general in accordance with the data in other larger series of patients. ${ }^{14}{ }^{15}$ Twenty four of the published patients were selected for 

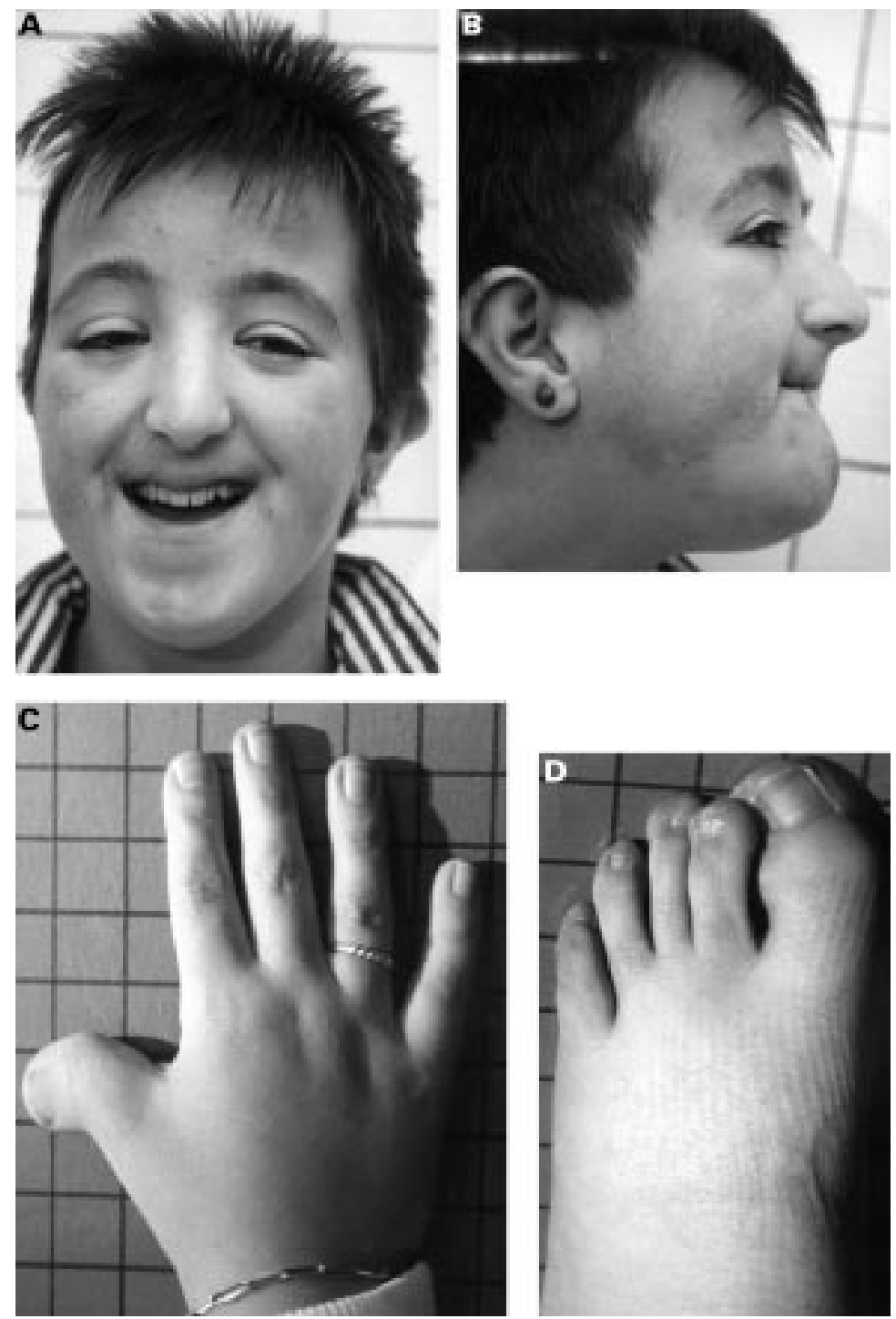

Figure 1 (A) Characteristic facial Rubinstein-Taybi syndrome in a 13 year old female patient. (B) Downward slanted palpebral fissures, long eyelashes, beaked nose, pouting lower lip, and mildly dysplastic and posteriorly rotated ears. (C) Typical hand characteristics in the same patient with Rubinstein-Taybi syndrome. (D) Typical foot characteristics in the same patient.

incorporation in the study. The selection was based solely on the distance between their homes and the institute where the investigation took place. All parents or guardians approved inclusion. The study was approved by the medical ethics committee of the Academic Medical Centre in Amsterdam.

OPHTHALMOLOGICAL INVESTIGATIONS

Complete ophthalmic examinations were performed on all patients. Visual acuity was assessed with two of the following methods: forced preferential looking, ${ }^{16}$ matching optotypes (HOTV), ${ }^{17}$ and Snellen visual acuity chart. Four patients could be tested with preferential looking only, because of age and mental development. Visual fields were tested with confrontation techniques. Only a limited number of patients were able to match and name colours. Therefore, testing with colour plates was not attempted. Pupillary responses, eye motility, strabismus, and the external aspects of the eyes and adnexa were assessed.
Slit lamp examination was performed in all patients. Funduscopy and retinoscopy were performed after cycloplegia except in one patient, in whom installation of eye drops was refused. In this patient examination of the optic disc was possible, but a reliable assessment of the macular region could not be made. Applanation tonometry was performed in four patients only; in most patients we did not attempt tonometry because of the risk of losing cooperation.

ELECTROPHYSIOLOGICAL INVESTIGATIONS

Visual evoked potentials (VEPs) were elicited with pattern onset stimuli, ${ }^{18}$ and recorded in all patients. Check sizes of 60', 30', 15', and 5' were used to evoke pattern onset responses. Electroretinography (ERG) was measured without sedation. Cooperation was insufficient in six patients for this examination, leaving 18 patients investigated. ERGs were recorded with Henkes' contact lens electrodes or, in less cooperative patients, DTL electrodes. In these mentally handicapped subjects measurements according to the standard ISCEV protocol were not possible, since the ISCEV protocol is lengthy and requires the patients to be in the dark for a long period of time. Therefore, we reduced the ERG protocol to the absolute minimum: a standard ISCEV flash photopic response (with a blue background of $10 \mathrm{~cd} / \mathrm{m}^{2}$ ) and a scotopic response ( $-2.0 \mathrm{ND}$ (Kodak Wratten filter) standard flash in the dark after 10 second dark adaptation). The stimulator consisted of an adapted dome, larger than normal, with mirrors, which allowed for a hospital bed with the subject lying down to be put below it. In this way, good (eye) contact of the patient with his or her parents remained possible. The recording equipment was kept in a separate room.

For this type of stimulation the normative values of the amplitudes are: scotopic (b-peak to onset) 66 (SD 27) $\mu \mathrm{V}$; photopic (b-peak to a-peak) 137 (64) $\mu \mathrm{V}$; mixed response (to the standard flash in the dark) 347 (94) $\mu \mathrm{V}$ (FCC Riemslag, unpublished data). Recording of the mixed response was possible in only nine patients.

\section{Results}

LITERATURE REVIEW

Eighty one reports describing 207 patients in sufficient detail were searched for ophthalmological features; 117 patients were found to have ocular abnormalities (Table 1). External, mainly (peri)ocular findings adding to the characteristic facial appearance were described in the majority of published cases: downward slanted palpebral fissures, hypertelorism, epicanthus, long eyelashes, ptosis (either unilateral or bilateral), and strabismus (Fig 1). The mentioning of these features depended heavily on the thoroughness of the descriptions of the patients by the different authors. Therefore, these features are not specifically mentioned in the table, and tabulation was restricted to severe problems in visual acuity, lacrimal apparatus anomalies, and intraocular findings. 
Table 1 Ocular symptoms in patients with Rubinstein-Taybi syndrome; 117 out of 207 patients (81 case reports)

\begin{tabular}{lll}
\hline Symptom & $\begin{array}{l}\text { Number with } \\
\text { symptom }\end{array}$ & References \\
\hline Lacrimal duct problems & 21 & $15,19-25$ \\
High myopia & 11 & $1,7,21,26-32$ \\
Nystagmus & 5 & $22,28,33-35$ \\
Pupillary abnormalities & 3 & $22,36,37$ \\
Microcornea/microphthalmia & 6 & $22,38-42$ \\
Corneal abnormalities & 23 & $1,21,30,31,40,43-49$ \\
Congenital glaucoma & 31 & $15,25,26,41,51,52,54-67$ \\
Iris atrophy & 2 & 30,68 \\
Congenital cataract & 15 & $15,21,24,26,27,33,38,39,41,53,69,70$ \\
Ectopia lentis & 1 & 37 \\
Microphakia & 1 & 28 \\
Coloboma (iris, lens, retinal, and/or optic nerve) & 39 & $1,15,19,24,27,28,39,42,48,51,72-83$ \\
Chorioretinal dystrophy & 6 & $32,84-88$ \\
Optic atrophy & 7 & $1,20,35,69,89,90$ \\
Optic disc abnormalities & 4 & $34,63,91,92$ \\
\hline
\end{tabular}

Lacrimal duct problems (21 cases), corneal abnormalities (that is, megalocornea without glaucoma, opacities, keratoglobus, sclerocornea) (23 cases), congenital glaucoma (31 cases), congenital cataract ( 15 cases), and colobomata (39 cases) were the most frequently described serious ocular abnormalities. No incidence figures of the various abnormalities can be extracted from these case reports, owing to ascertainment bias and publishing of incomplete data of ophthalmological investigations in the majority of cases. In 1990, Rubinstein $^{14}$ reviewed 571 individuals with RTs gathered both from literature and from personal investigations or personal communications with other physicians worldwide. Refractive errors were seen in $56 \%$ of cases, strabismus in $71 \%$, ptosis in $29 \%$, and lacrimal duct anomalies in $37 \%$ of cases. No data regarding the frequency of other eye anomalies were provided.

FINDINGS IN 24 DUTCH PATIENTS

All major results are summarised in Tables 2 and 3 . Five patients $(20 \%)$ were visually handi- capped with a visual acuity equal to or below 0.3 . Visual fields were normal in all patients. Strabismus was found in 17 patients (67\%). Refractive errors were common: six patients (25\%) were highly myopic (excess of -6 dioptres). Photophobia occurred in 11 patients: in four, possible causes were found (cataract in two, corneal herpes infection in one, pterygium in one case), but in seven the photophobia could not be explained by anterior segment abnormalities. Nasolacrimal duct obstruction occurred in six cases (25\%), in two of them unilaterally. Three cases had severe congenital ocular abnormalities: congenital cataract and colobomata, congenital glaucoma, and unilateral microphthalmia with congenital cataract, respectively. Two other cases had congenital cataracts that did not cause significant visual disability and were therefore left untreated. Two patients had presenile or secondary cataracts.

On funduscopy, macular abnormalities were found in 18 patients $(75 \%)$. Thirteen cases had mild macular abnormalities - that is, abnormal or absent reflexes, increased reddening of the

Table 2 Ocular examination in 24 patients with Rubinstein-Taybi syndrome: external aspect and anterior segment

\begin{tabular}{|c|c|c|c|c|c|c|c|c|c|c|c|c|c|c|}
\hline \multirow[b]{2}{*}{ Patient } & \multirow[b]{2}{*}{ Age } & \multirow[b]{2}{*}{ Sex } & \multirow[b]{2}{*}{ Strabismus* } & \multirow[b]{2}{*}{ Nystagmus } & \multicolumn{2}{|c|}{$\begin{array}{l}\text { Lacrimal duct } \\
\text { problems }\end{array}$} & \multicolumn{2}{|c|}{$\begin{array}{l}\text { Cornea } \\
\text { anomaliest }\end{array}$} & \multicolumn{2}{|c|}{$\begin{array}{l}\text { Intraocular } \\
\text { pressure } \neq\end{array}$} & \multicolumn{2}{|c|}{ Iris anomalies $\int$} & \multicolumn{2}{|c|}{ Cataract } \\
\hline & & & & & $R E$ & $L E$ & $R E$ & $L E$ & $R E$ & $L E$ & $R E$ & $L E$ & $R E$ & $L E$ \\
\hline a & 4 & M & div alt & + & - & - & & & & & & & - & - \\
\hline b & 6 & M & - & - & - & - & $\mathrm{i}$ & & & & & & - & - \\
\hline c & 6 & M & - & - & - & - & & & 15 & 16 & & & & \\
\hline d & 7 & M & div RE & - & + & + & & & & & & & + & + \\
\hline e & 7 & M & div alt & - & + & - & & & & & & & - & - \\
\hline $\mathrm{f}$ & 8 & $\mathrm{~F}$ & div alt & - & - & - & & & & & & & - & - \\
\hline $\mathrm{g}$ & 9 & $\mathrm{~F}$ & conv alt & - & - & - & & & & & & & - & - \\
\hline $\mathrm{h}$ & 10 & $\mathrm{~F}$ & - & - & - & - & & & & & & & - & - \\
\hline $\mathrm{i}$ & 12 & $\mathrm{~F}$ & div LE & - & - & - & buph & buph & 13 & 14 & & he & - & + \\
\hline j & 14 & M & - & + & - & - & & & & & & & - & - \\
\hline $\mathrm{k}$ & 15 & M & div alt & - & - & - & & & & & & & - & - \\
\hline 1 & 15 & M & div LE & - & + & + & & & & & hy & hy & + & + \\
\hline $\mathrm{m}$ & 15 & $\mathrm{~F}$ & div alt & - & - & - & & & & & & & - & - \\
\hline $\mathrm{n}$ & 19 & $\mathrm{~F}$ & - & + & + & - & & & 9 & & & & + & - \\
\hline o & 21 & $\mathrm{~F}$ & div alt & - & - & - & & & & & & & - & - \\
\hline $\mathrm{p}$ & 24 & M & conv LE & + & - & - & & & & & & & - & - \\
\hline$q$ & 24 & $\mathrm{~F}$ & div LE & - & - & - & & & & & & & - & - \\
\hline $\mathrm{r}$ & 29 & $\mathrm{~F}$ & div LE & - & - & - & & & & & $\mathrm{f}$ & $\mathrm{f}$ & - & - \\
\hline $\mathrm{s}$ & 30 & $\mathrm{~F}$ & - & - & + & + & & & 14 & 18 & & & - & - \\
\hline $\mathrm{t}$ & 34 & M & div $R E$ & - & + & + & pt & & & & & & - & - \\
\hline $\mathrm{u}$ & 36 & $\mathrm{~F}$ & div alt & - & - & - & & & & & & & - & - \\
\hline $\mathrm{v}$ & 37 & $\mathrm{~F}$ & div LE & - & - & - & & & & & & & - & - \\
\hline $\mathrm{w}$ & 43 & M & - & - & - & - & & & & & & cy & + & $+\#$ \\
\hline $\mathrm{x}$ & 44 & M & div LE & - & - & - & & & & & & & - & + \\
\hline
\end{tabular}

${ }^{\star}$ conv $=$ convergent; div $=$ divergent

$\mathrm{tpt}=$ pterygium; $\mathrm{i}=$ herpes infection; buph $=$ buphthalmus

$\neq$ measured with applanation tonometry.

She $=$ heterochromia $;$ hy $=$ hypoplasia $; \mathrm{f}=$ flattened $\mathrm{cy}=$ colobomatous eye, prosthesis after enucleation

$\uparrow+\#=$ congenital cataract and colobomata, prosthesis after enucleation 
Table 3 Ocular examination in 24 patients with Rubinstein-Taybi syndrome: visual acuity, refraction, funduscopy, and electrophysiology

\begin{tabular}{|c|c|c|c|c|c|c|c|c|c|c|c|c|c|c|}
\hline & \multirow[b]{3}{*}{ Age } & \multirow{2}{*}{\multicolumn{3}{|c|}{ Visual acuity ${ }^{*}$}} & \multirow{2}{*}{\multicolumn{2}{|c|}{ Refraction (spher eq) }} & \multirow{3}{*}{$\begin{array}{l}\text { Photo- } \\
\text { phobia }\end{array}$} & \multicolumn{5}{|l|}{ Retina } & \multirow[b]{3}{*}{$E R G$ a } & \multirow[b]{3}{*}{$V E P q$} \\
\hline & & & & & & & & \multicolumn{2}{|l|}{ maculat } & \multicolumn{2}{|c|}{ optic disc $\neq$} & \multirow[b]{2}{*}{ othery } & & \\
\hline & & $R E$ & $L E$ & $O D S$ & $R E$ & $L E$ & & $R E$ & $L E$ & $R E$ & $L E$ & & & \\
\hline a & 4 & $\mathrm{~nm}$ & $\mathrm{~nm}$ & 0.5 & $S+1$ & $S+1$ & - & $M(r, f)$ & $M(r, f)$ & - & - & - & $\mathrm{nm}$ & $\mathrm{N}$ \\
\hline $\mathrm{b}$ & 6 & $\mathrm{~nm}$ & $\mathrm{~nm}$ & 0.3 & $S+1$ & $S+0.5$ & + & - & - & - & - & - & $\mathrm{C}, \mathrm{R}$ & $a b n$ \\
\hline c & 6 & 1.0 & 1.0 & 1.0 & $S+4.75$ & $S+5$ & + & $M(f)$ & $M(f)$ & - & - & - & $\mathrm{nm}$ & $a b n$ \\
\hline d & 7 & 0.5 & 0.5 & 0.75 & $\mathrm{E}$ & $\mathrm{E}$ & - & $M(f)$ & $M(f)$ & $\mathrm{p}$ & $\mathrm{p}$ & - & $\mathrm{C}$ & abn \\
\hline $\mathrm{e}$ & 7 & 1.0 & 1.0 & 1.0 & $\mathrm{E}$ & $\mathrm{E}$ & - & $M(\mathrm{r}, \mathrm{f})$ & $M(r, f)$ & $\mathrm{e}$ & $\mathrm{e}$ & - & $\mathrm{C}, \mathrm{R}$ & $a b n$ \\
\hline $\mathrm{f}$ & 8 & 1.0 & 1.0 & 1.0 & $\mathrm{~S}+2.5$ & $\mathrm{~S}+2.5$ & + & $M(r)$ & $M(r)$ & - & - & - & $\mathrm{C}$ & abn \\
\hline $\mathrm{g}$ & 9 & 0.3 & 0.25 & 0.5 & $S-2$ & $S-2$ & + & - & - & - & - & - & $\mathrm{nm}$ & $\mathrm{N}$ \\
\hline $\mathrm{h}$ & 10 & 1.0 & 1.0 & 1.0 & $\mathrm{E}$ & $\mathrm{E}$ & - & - & - & $\mathrm{e}$ & $\mathrm{e}$ & - & $\mathrm{N}$ & $\mathrm{N}$ \\
\hline $\mathrm{i}$ & 12 & 0.75 & NLP & 0.75 & $\mathrm{E}$ & $\mathrm{nm}$ & - & $M(r)$ & $M(\mathrm{~m})$ & $\mathrm{e}$ & $\mathrm{e}$ & - & $\mathrm{N}$ & abn \\
\hline $\mathrm{j}$ & 14 & 0.75 & 0.5 & 0.75 & $S-2.5$ & $S-7.5$ & - & $M(\mathrm{~m})$ & $M(\mathrm{~m})$ & $\mathrm{p}$ & - & - & C & $\mathrm{N}$ \\
\hline $\mathrm{k}$ & 15 & 0.5 & 0.5 & 0.5 & $\mathrm{~S}+2.5$ & $S+2.5$ & + & $M(r)$ & $M(r)$ & $\mathrm{p}$ & $\mathrm{p}$ & - & $\mathrm{C}$ & abn \\
\hline 1 & 15 & 0.75 & 0.5 & 0.75 & $S+1$ & $S+1$ & - & - & $M(f)$ & $\mathrm{e}$ & e & - & $\mathrm{N}$ & $\mathrm{N}$ \\
\hline $\mathrm{m}$ & 15 & 1.0 & 1.0 & 1.0 & $S-2$ & $S-2$ & + & - & - & $\mathrm{e}$ & $\mathrm{e}$ & - & $\mathrm{nm}$ & $\mathrm{N}$ \\
\hline $\mathrm{n}$ & 19 & LP & 0.5 & 0.5 & $\mathrm{~nm}$ & $S-9$ & + & ne & $\mathrm{S}(\mathrm{PE})$ & $\mathrm{nm}$ & $\mathrm{p}$ & - & $\mathrm{C}, \mathrm{R}$ & abn \\
\hline o & 21 & $\mathrm{~nm}$ & $\mathrm{~nm}$ & 0.3 & $\mathrm{~S}+2$ & $S+3$ & + & ne & ne & - & - & - & $\mathrm{nm}$ & $a b n$ \\
\hline $\mathrm{p}$ & 24 & 0.5 & 0.25 & 0.5 & $S+1$ & $S+1$ & - & - & $\mathrm{M}(\mathrm{PE})$ & - & - & - & $\mathrm{C}, \mathrm{R}$ & $\mathrm{N}$ \\
\hline $\mathrm{q}$ & 24 & 0.5 & 0.5 & 0.5 & $S-1.5$ & $S-1$ & - & $M(f)$ & $M(f)$ & $\mathrm{e}$ & - & - & $\mathrm{C}, \mathrm{R}$ & abn \\
\hline $\mathrm{r}$ & 29 & 0.75 & 0.5 & 0.75 & $S-3$ & $S-19$ & - & $\mathrm{S}(\mathrm{PE})$ & $\mathrm{S}(\mathrm{PE})$ & $\mathrm{m}$ & $\mathrm{m}$ & - & $\mathrm{C}$ & $a b n$ \\
\hline $\mathrm{s}$ & 30 & 0.75 & 0.75 & 0.75 & $S-6.5$ & $S-7$ & - & - & - & - & $\mathrm{e}$ & - & $\mathrm{N}$ & $\mathrm{N}$ \\
\hline $\mathrm{t}$ & 34 & 0.25 & 0.3 & 0.3 & $S-7$ & $S-7$ & + & $\mathrm{S}(\mathrm{PE})$ & $\mathrm{S}(\mathrm{PE})$ & $\mathrm{m}$ & $\mathrm{m}$ & - & C & $a b n$ \\
\hline $\mathrm{u}$ & 36 & 0.5 & 0.5 & 0.5 & $S+3$ & $S+2.5$ & + & $\mathrm{S}(\mathrm{PE})$ & $\mathrm{S}(\mathrm{PE})$ & $\mathrm{e}$ & $\mathrm{e}$ & - & C & abn \\
\hline $\mathrm{v}$ & 37 & 0.5 & 0.5 & 0.5 & $S-2$ & $S-1.5$ & - & $M(r)$ & $M(r)$ & $e, p$ & $e, p$ & c & $\mathrm{C}, \mathrm{R}$ & $a b n$ \\
\hline $\mathrm{w}$ & 43 & 0.1 & NLP & 0.1 & $S-2.5$ & pros & - & $M(r)$ & pros & $\mathrm{p}$ & pros & & $\mathrm{C}$ & $\mathrm{N}$ \\
\hline $\mathrm{x}$ & 44 & 0.25 & LP & 0.25 & $S-22$ & $S-22$ & + & S (deg) & S (deg) & $\mathrm{m}$ & $\mathrm{m}$ & - & $\mathrm{nm}$ & abn \\
\hline
\end{tabular}

$\star_{\mathrm{nm}}=$ not measurable

$\dagger \mathrm{M}=$ mild changes; $\mathrm{S}=$ severe changes; $\mathrm{r}=$ abnormal or absent reflexes; $\mathrm{f}=$ fovea too red; $\mathrm{PE}=$ pigment epithelium alterations; ne $=$ could not be examined in detail; $\mathrm{m}=$ myopic; $\operatorname{deg}=$ myopic degeneration; pros = prosthesis.

$\ddagger$ e excavated $\mathrm{m}=$ myopic, $\mathrm{p}=$ pale; pros $=$ prosthesis

$\int \mathrm{c}=$ coloboma.

anm $=$ not measured $\mathrm{C}=$ decreased cone responses; $\mathrm{R}=$ decreased rod responses; $\mathrm{N}=$ normal.

qN = normal;abn = abnormal.

foveal area, or unusual distribution of pigmentation in the posterior pole (Fig 2). Five cases had more severe macular abnormalities. Pigmentary macular changes and atrophy were seen in patients "n", "t" (Fig 3), and "u". Two of these patients were myopic, but the degree of macular changes was much more severe than expected with regard to age and rate of myopia. Patient " $r$ " showed lacquer cracks as a result of high myopia in her left eye, but her right eye, which had only mild myopia, also showed pigmentary changes. Patient " $x$ ", who had a myopia of -22 dioptres, had severe myopic degeneration. Patient " $v$ " had a small chorioretinal coloboma (Fig 4).

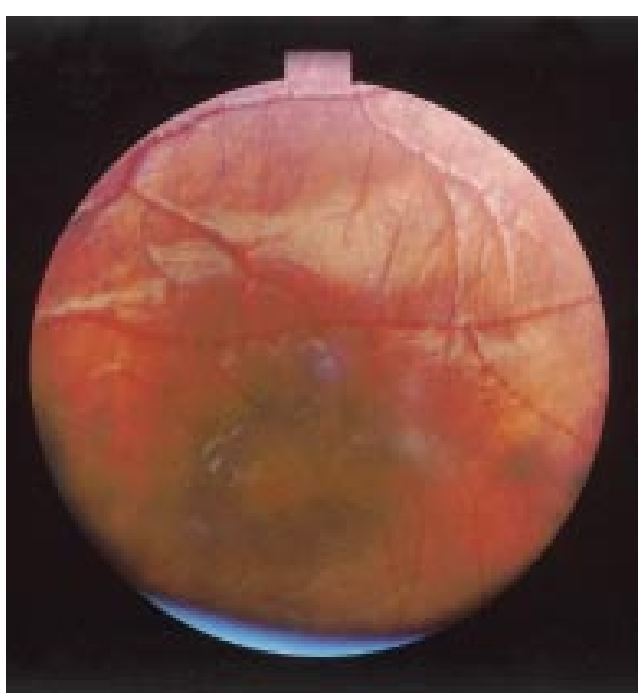

Figure 2 Seven year old male patient with Rubinstein-Taybi syndrome, showing mild macular abnormalities: unusual distribution of pigment, red foveal area.
Visual evoked potentials showed an abnormal waveform in 15 patients $(62.5 \%)$ with a missing striate or foveal component. In Figure 5 the responses of a subject with normal vision and fundus (VODS $>1.0$ ), a patient with RTs, and a patient with achromatopsia are shown for comparison. As is known from previous research, ${ }^{93-95}$ the first (normal) subject shows a response composed of a striate component (predominantly negative, peak latency at approximately $110 \mathrm{~ms}$ ), and a extrastriate component (positive negative, the positivity at about $80 \mathrm{~ms}$, the negativity at $160-200 \mathrm{~ms}$ ). As the check sizes become smaller, the striate component becomes more prominent, the extrastriate component diminishes in ampli-

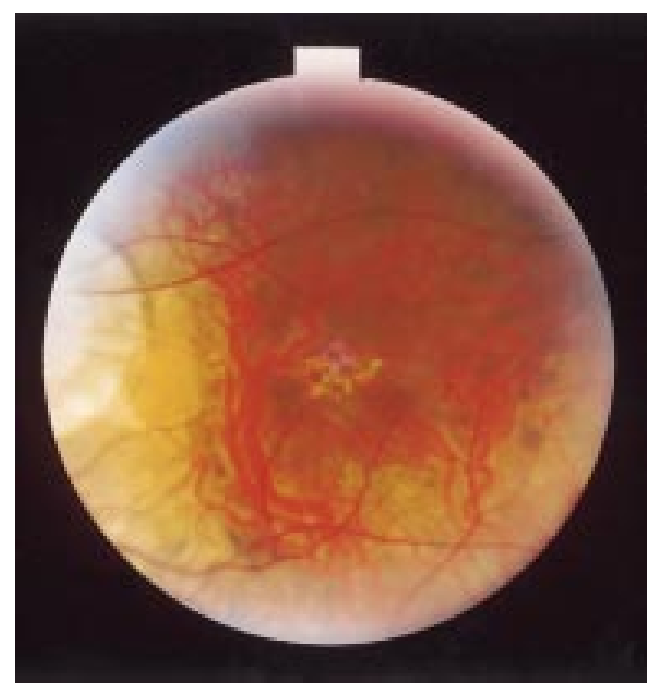

Figure 3 Fundus of 34 year old patient with Rubinstein-Taybi syndrome with retinal pigment epithelial changes. 


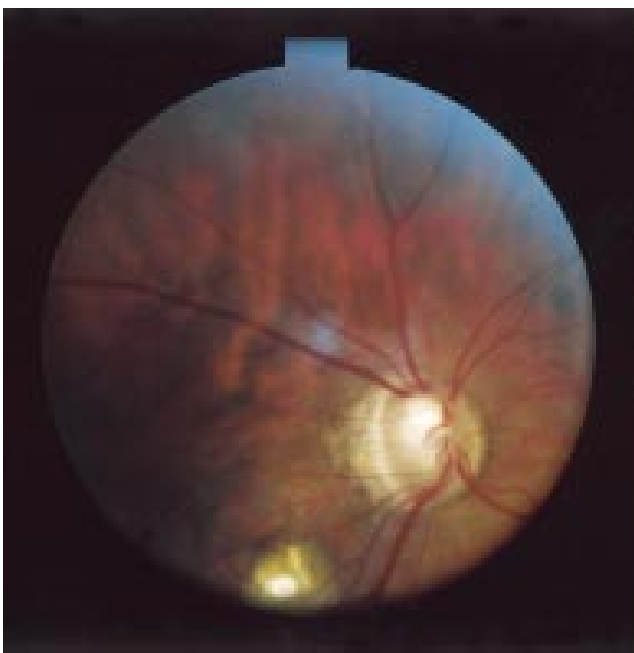

Figure 4 Right fundus of 37 year old female patient with Rubinstein-Taybi syndrome showing a pale and excavated optic disc and a small chorioretinal coloboma.

tude. In the (characteristic) response of an RTs patient, only an extrastriate component is seen (positive negative, P100, N180); this response diminishes in amplitude with decreasing check size. For the achromat, only the biggest check sizes $\left(60^{\prime}\right)$ evoke a significant response, also only containing an extrastriate contribution (note the differences in the voltage scale).

Of the 18 ERGs recorded $14(78 \%)$ showed anomalies. Eight ERGs showed decreased cone responses and six ERGs showed decreased cone and rod responses.

\section{Discussion}

The great variety of ocular abnormalities, involving all eye segments, that occurs in Rubinstein-Taybi syndrome is remarkable, and

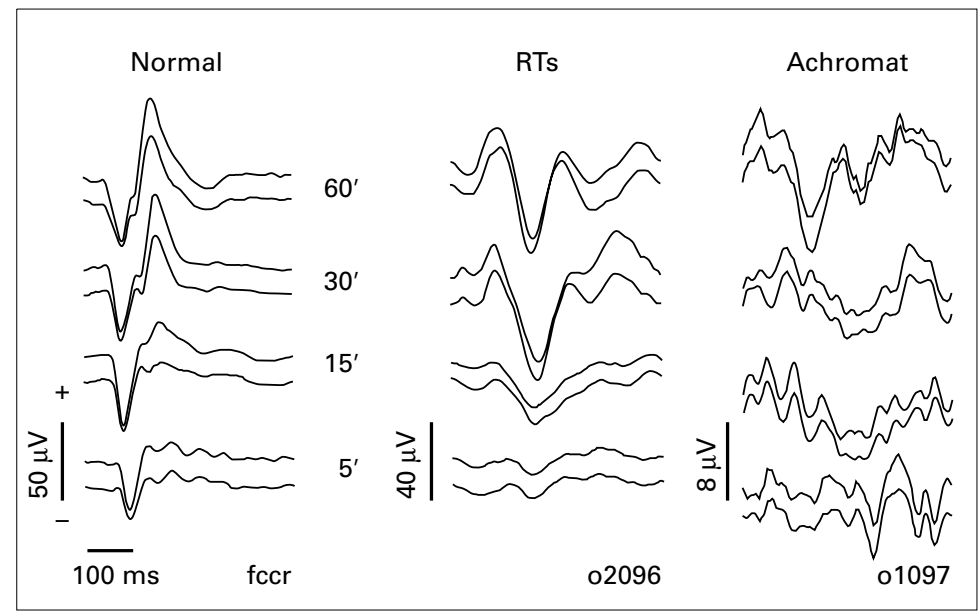

Figure 5 Pattern onset visual evoked potentials of a normal subject (left), patient with RTs (middle), and patient with achromatopsia (right).

Table 4 Frequency of external ocular abnormalities in our patients compared with 571 patients reviewed by Rubinstein ${ }^{14}$ and 50 patients from a questionnaire study of Stevens ${ }^{15}$

\begin{tabular}{|c|c|c|c|c|c|c|}
\hline & Strabismus & $\begin{array}{l}\text { Refractive } \\
\text { error* }\end{array}$ & $\begin{array}{l}\text { Nasolacrimal } \\
\text { duct } \\
\text { obstruction }\end{array}$ & Cataract & Colobomat & Glaucomat \\
\hline Rubinstein (n=571) & $71 \%$ & $56 \%$ & $37 \%$ & $\mathrm{~nm}$ & $\mathrm{~nm}$ & $\mathrm{~nm}$ \\
\hline Stevens $(n=50)$ & $48 \%$ & $38 \%$ & $30 \%$ & $6 \%$ & $6 \%$ & $2 \%$ \\
\hline Our patients $(n=24)$ & $71 \%$ & $67 \%$ & $25 \%$ & $20 \%$ & $8 \%$ & $4 \%$ \\
\hline
\end{tabular}

${ }^{\star}$ More than 1 dioptre.

$t_{\mathrm{nm}}=$ not mentioned. provides another indication for the ubiquitous functions of CBP. Two previous studies of RTs patients $^{14}{ }^{15}$ showed a frequency of ocular abnormalities comparable to the frequency of abnormalities in our patients (Table 4). However, they did not report on retinal dysfunction, and in literature only six cases with possible retinal dystrophy were published..$^{32-88}$ In these cases fundus abnormalities such as pigmentary changes, absent foveal reflexes, and/or a dystrophic retina were described. In two patients an ERG was made ${ }^{3287}$; one was attenuated. ${ }^{32}$ In one patient ${ }^{88}$ a VEP was made which was stated to be normal. However, the authors did not mention whether or not the VEP was a flash, pattern onset, or pattern reversal VEP. The abnormal waveforms we report on here can only be seen in pattern onset VEPs, with the standard pattern reversal responses being normal.

Approximately a third of the patients from the literature were examined by paediatricians. Routine examination by an ophthalmologist was mentioned only in a few cases. Most patients seemed to have been assessed by an ophthalmologist only if they had obvious ocular abnormalities. This may account for the higher frequency in literature of external abnormalities (that is, cornea, congenital glaucoma) compared with fundus changes. Furthermore, as in our patients, fundus changes may have been mostly mild, not leading to a diagnosis of retinal dystrophy without ERG measurements.

According to the World Health Organization definition, a person is considered visually handicapped if the person's best corrected binocular visual acuity is at or below 0.3 . In this study, five patients were visually handicapped $(21 \%)$. In addition, three other patients had a low visual acuity in only one eye. Although congenital or presenile cataract occurred frequently in our patients $(25 \%)$, only in one patient the visual handicap was caused by cataract.

In contrast with the low incidence in literature, $78 \%$ of the present patients showed signs of retinal dysfunction as measured by ERG. In general, an abnormal ERG is caused by abnormally functioning of photoreceptors, bipolar cells, and Müller cells. Abnormally functioning of the retinal pigment epithelium (RPE) can also result in ERG disturbances, as the RPE is necessary for normal functioning of the photoreceptors. All abnormal ERGs showed a decreased cone response, indicating cone dysfunction. Seven patients had unexplained photophobia. Photophobia is often seen in patients with cone dysfunction.

The abnormal waveform in VEP testing was assumed to be caused by the abnormally functioning retina. A normal pattern onset VEP has a striate component that for the largest part is determined by foveal function. This component was missing in all abnormal VEPs. If there are no normally functioning cones, there will be an abnormal or absent striate component in the VEP. A similar waveform can be found in the VEPs of patients with total absence of functioning cones - that is, achromatopsia. ${ }^{96} 97$ 
Table 5 Increasing incidence of fundus, ERG, and VEP abnormalities with age

\begin{tabular}{|c|c|c|c|c|c|c|c|c|}
\hline \multirow{2}{*}{$\begin{array}{l}\text { Age } \\
\text { (years) }\end{array}$} & \multicolumn{3}{|c|}{ Fundus abnormalities } & \multicolumn{3}{|l|}{$E R G$} & \multicolumn{2}{|l|}{$V E P$} \\
\hline & none & mild & severe & normal & cone & cone rod & normal & abnormal \\
\hline$<15$ & $4 / 13(31 \%)$ & $9 / 13(69 \%)$ & 0 & $3 / 9(33 \%)$ & $4 / 9(44 \%)$ & $2 / 9(22 \%)$ & $6 / 13(46 \%)$ & $7 / 13(54 \%)$ \\
\hline $15-30$ & $1 / 5(20 \%)$ & $2 / 5(40 \%)$ & $2 / 5(40 \%)$ & $1 / 5(20 \%)$ & $1 / 5(20 \%)$ & $3 / 5(60 \%)$ & $2 / 6(33 \%)$ & $4 / 6(67 \%)$ \\
\hline$>30$ & 0 & $2 / 5(40 \%)$ & $3 / 5(60 \%)$ & $0 / 4(0 \%)$ & $3 / 4(75 \%)$ & $1 / 4(25 \%)$ & $1 / 5(20 \%)$ & $4 / 5(80 \%)$ \\
\hline
\end{tabular}

As demonstrated in Figure 5 in which the responses in individuals with RTs subjects are compared with the responses of achromat individuals, the responses share the absence of a striate component. The extrastriate component in the RTs individuals is evoked for various check sizes, whereas in the achromat people it is classically found only for the largest check sizes. This suggests in general a better visual acuity for the RTs patients compared with the achromats, which is corroborated by the presently reported findings.

In four patients the VEP and ERG were not in accordance: three times the ERG was subnormal with a normal VEP, and once a normal ERG was registered with an abnormal VEP. Because an ERG measures the overall activity of the retina, locally abnormally functioning cones can give rise to an abnormal VEP without significant influence on the ERG. On the other hand, if the dysfunction of the photoreceptors is widespread but macular vision is preserved, the ERG can be grossly abnormal with a normal VEP. ${ }^{100} 101$ In the majority of patients in which an ERG could be measured, the ERG and VEP were in accordance $(78 \%)$. Furthermore, the abnormal VEPs of patients with normal ERGs showed the same extrastriate pattern as the VEPs of patients with attenuated ERGs. Therefore, in patients in which an ERG could not be performed, we considered the abnormal VEP a sign of retinal dysfunction.

The incidence of abnormal ERGs and VEPs as well as of retinal abnormalities increases

Table 6 ERG values of 24 patients with Rubinstein-Taybi syndrome

\begin{tabular}{|c|c|c|c|c|}
\hline \multirow[b]{2}{*}{ Patient } & \multirow[b]{2}{*}{ Age } & \multicolumn{3}{|l|}{$E R G$} \\
\hline & & Photopic & Scotopic & Mixed \\
\hline Normal values (SD) & & $137(64)(n=18)$ & $66(27)(\mathrm{n}=18)$ & $347(94)(n=18)$ \\
\hline a & 4 & $\mathrm{~nm}$ & $\mathrm{~nm}$ & $\mathrm{~nm}$ \\
\hline b & 6 & $7^{\star}$ & $0 \star \star \star$ & $\mathrm{nm}$ \\
\hline c & 6 & $\mathrm{~nm}$ & $\mathrm{~nm}$ & $\mathrm{~nm}$ \\
\hline d & 7 & $69^{\star}$ & 53 & $\mathrm{~nm}$ \\
\hline e & 7 & $20^{\star}$ & $33^{\star}$ & $\mathrm{nm}$ \\
\hline $\mathrm{f}$ & 8 & $45^{\star}$ & 77 & $218^{\star}$ \\
\hline $\mathrm{g}$ & 9 & $\mathrm{~nm}$ & $\mathrm{~nm}$ & $\mathrm{~nm}$ \\
\hline $\mathrm{h}$ & 10 & 80 & 58 & 305 \\
\hline $\mathrm{i}$ & 12 & 82 & 110 & 266 \\
\hline j & 14 & $55^{\star}$ & 94 & $132^{\star}$ \\
\hline $\mathrm{k}$ & 15 & $35^{\star}$ & 56 & $\mathrm{~nm}$ \\
\hline 1 & 15 & 86 & 82 & $222^{\star}$ \\
\hline $\mathrm{m}$ & 15 & $\mathrm{~nm}$ & $\mathrm{~nm}$ & $\mathrm{~nm}$ \\
\hline $\mathrm{n}$ & 19 & $39^{\star}$ & $0 \star \star \star$ & $\mathrm{nm}$ \\
\hline o & 21 & $\mathrm{~nm}$ & $\mathrm{~nm}$ & $\mathrm{~nm}$ \\
\hline $\mathrm{p}$ & 24 & $45^{\star}$ & $34^{\star}$ & $112^{\star \star}$ \\
\hline$q$ & 24 & $53^{\star}$ & $0 \star \star \star$ & $95^{\star \star}$ \\
\hline $\mathrm{r}$ & 29 & $53^{\star}$ & 99 & $137^{\star \star}$ \\
\hline $\mathrm{s}$ & 30 & 75 & 51 & 280 \\
\hline $\mathrm{t}$ & 34 & $27^{\star}$ & 138 & $222^{\star}$ \\
\hline $\mathrm{u}$ & 36 & $30^{\star}$ & $\mathrm{nm}$ & $\mathrm{nm}$ \\
\hline $\mathrm{v}$ & 37 & $36^{\star}$ & $0 \star \star \star$ & $\mathrm{nm}$ \\
\hline $\mathrm{w}$ & 43 & $39^{\star}$ & 52 & $\mathrm{~nm}$ \\
\hline $\mathrm{x}$ & 44 & $\mathrm{~nm}$ & $\mathrm{~nm}$ & $\mathrm{~nm}$ \\
\hline
\end{tabular}

$\star<1$ SD below the mean.

$\star \star<2$ SD below the mean. with age (Table 5), suggesting a progressive retinal dystrophy. However, only future careful follow up will allow any firm conclusions regarding progression with age. Retinal dystrophy comprises a genetically heterogeneous group of disorders, which can occur in a wide variety of systemic disorders. ${ }^{100} 101$ The occurrence of retinal dystrophy in RTs means that expression of the defective gene causing RTs is also present in the retina.

In 18 patients, funduscopy, electrophysiology, or both, showed signs of retinal dysfunction, but in four patients both were normal. ERG changes occur very early in retinal dystrophy, most often before any retinal changes are seen (Table 6). Hence, it is less likely that in the latter four patients retinal dystrophy will yet develop, but three of these patients are still children and without follow up this can not be concluded with certainty. If retinal dystrophy will indeed not arise, this indicates phenotypic heterogeneity with regard to retinal function. It is uncertain whether this can merely be explained by the pleiotropic expression of the abnormal CBP gene in RTs, or is an indication for genetic heterogeneity in RTs. In a limited number of the present patients cytogenetic studies using fluorescence in situ hybridisation techniques, and molecular studies have been performed. All (seven) cases in whom either a submicroscopic deletion or a mutation in the CBP gene have been found until now, also showed the electrophysiological abnormalities (data not shown). This suggests that the presence or absence of the electrophysiological abnormalities may be indicative for the presence or absence of abnormalities involving the CBP gene, and suggests genetic heterogeneity. However, before such conclusion can be drawn all patients, both with and without electrophysiological abnormalities, should be investigated cytogenetically using FISH for microdeletions at chromosome 16 p13.3 and molecularly for mutations in the CBP gene. Such studies are in progress.

1 Rubinstein JH, Taybi H. Broad thumbs and toes and facial abnormalities. Am f Dis Child 1963;105:88-108.

2 Hennekam RCM, Stevens CA, Van De Kamp JJP. Etiology and recurrence risk in Rubinstein-Taybi syndrome. $A m \mathcal{F}$ Med Genet (Suppl) 1990;6:56-64.

3 Gorlin RJ, Cohen MM, Hennekam RCM. Syndromes of the head and neck. 4th ed. London: Oxford Medical Press, in press.

4 Breuning MH, Dauwerse HG, Fugazza G, et al. RubinsteinTaybi syndrome caused by submicroscopic deletions within 16p13.3. Am $\mathcal{F}$ Hum Genet 1993;52:249-54.

5 Petrij F, Giles RH, Dauwerse HG, et al. Rubinstein-Taybi syndrome caused by mutations in the transcriptional co-activator CBP. Nature 1995;376:348-51.

6 Taine L, Goizet C, Qi Wen Z, et al. Submicroscopic deletion of chromosome 16 p13.3 im patients with Rubinstein-Taybi syndrome. Am f Med Genet 1998;78:267-70.

7 Harel T, Silverstone BZ, Seelenfreund M, et al. Retinal detachment with high myopia in the Rubinstein-Taybi syndrome. Med Ped Syst Ophthalmol 1991;14:31-4. 
8 Brei TJ, Burke MJ, Rubinstein JH. Glaucoma and findings simulating glaucoma in the Rubinstein-Taybi syndrome. $f$

9 Cruz OA, Mason DM, Eswara MS, et al. Duane retraction syndrome associated with Rubinstein-Taybi syndrome. Ophthalmol Genet 1995;16:171-5.

$10 \mathrm{Ge}$ N, Crandall BF, Shuler JD, et al. Coloboma associated with Rubinstein-Taybi syndrome. I Pediatr Ophthalmol Strabismus 1995;32:266-8

11 Quaranta L, Quaranta CA. Congenital glaucoma associated with Rubinstein-Taybi syndrome. Acta Ophthalmol Scand 1998;76:112-3

12 Hennekam RCM. Bibliography on Rubinstein-Taybi syndrome. Am f Med Genet (Suppl) 1990;6:77-83.

13 Hennekam RCM, Tilanus M, Hamel BCJ, et al. Deletion at chromosome 16 p13.3 as a cause of Rubinstein-Taybi syndrome: clinical aspects. Am f Hum Genet 1993;52:255syn 2 .

14 Rubinstein JH. Broad thumb-hallux (Rubinstein-Taybi) syndrome 1957-1988. Am F Med Genet (Suppl) 1990;6:316 .

15 Stevens CA, Carey JC, Blackburn BL. Rubinstein-Taybi syndrome: a natural history study. Am $\mathcal{F}$ Med Genet (Suppl) 1990;6:30-7.

16 Teller D, McDonald M, Preston K, et al. Assessment of visual acuity in infants and children: the acuity card procedure. Dev Med Child Neurol 1986;28:770-90.

17 Simons K. Visual acuity norms in young children. Surv Ophthalmol 1983;28:84-92.

18 Spekreijse H. Analysis of the EEG responses to diffuse and to patterned light in human. The Hague: JW Junk Publishers, 1966.

19 Berg JM, Smith GF, Ridler MAC, et al. On the association of broad thumbs and first toes with other physical pecularities and mental retardation. F Ment Defic Res 1966;10:20420.

20 Neuhauser G, Schulze H. Das Rubinstein-Taybi-Syndrom. Zeitschr fur Kinderheilkd 1968;103:90-108.

21 Roy FH, Summitt RL, Hiatt RL, et al. Ocular manifestations of the Rubinstein-Taybi syndrome. Arch Ophthalmol 1968;
79:272-8.

22 Behrens-Baumann W. Augensymptome beim RubinsteinTaybi-Syndrom. Klin Monatsbl Augenheilkd 1977;171:12635.

23 López Delgado J, Estefania Gallardo C, Santano M, et al. Síndrome de Rubinstein y Taybi. Rev Esp Pediatr 1981;37: 157-62.

24 Del Castillo F, Lopez Martin V, Rodriguez Costa T, et al. Sindrome de Rubinstein-Taybi (Estudio sobre ocho casos). Arch Neurobiol (Madr) 1972;35:425-52.

25 Filippi G. The Rubinstein-Taybi syndrome: report of 7 cases. Clin Genet 1972;3:303-18.

26 Goncalves A, Safadi NJ. Sindrome Rubinstein-Taybi. Rev Bras Oftalmol 1975;34:161-6.

27 Johnson CF. Broad thumbs and broad great toes with facial abnormalties and mental retardation. $₹$ Pediatr $1966 ; 68$ 942-51.

28 Klein D, Rubinstein JH, Ammann F. Caracteristiques neuro-ophtalmologiques du syndrome des "pouces larges" de Rubinstein-Taybi. Oto-Neuro-Ophthalmol 1972;44:37382.

29 Lamy M, Jammet M-L, Ajjan N, et al. Le syndrome de Rubinstein-Taybi. Arch Fr Pédiatr 1967;24:472.

30 Legrand J, Maurat J-Cl. Contribution à l'étude de Syndrome de Rubinstein-Taybi. Arch Ophtalmol Paris 1973;33:641-60.

31 Thomas ML, Philip E. Rubinstein-Taybi syndrome. Indian $\mathcal{f}$ Pediatr 1967;4:358-60.

32 Felgenhauer WR. Syndrome de Rubinstein-Taybi. Humangenetik 1973;20;63-9.

33 Maciel JA, Da Silva RJM, De Oliveira AJ. Syndrome de Rubinstein-Taybi; description d'une observation clinique. Rev Oto-Neurol-Ophthalmol (Paris) 1977;49:169-75.

34 Theile U, Draf U, Heldt JP. Das Rubinstein-Taybi-Syndrom. Dtsch Med Wschr 1978;103:1505-10

35 Völcker HE, Haase W. Augensymptomatik beim Rubinstein-Taybi-Syndrom. Klin Monatsbl Augenheilkd 1975;167: 478-83.

36 Negrier EG. Sindroma de Rubinstein y Taybi. Rev Chil Pediatr 1970;41:446-9.

37 Pérez Scheriff A, Villa Elizaga P, De la Calle Contreras R, et al. Dos nuevos casos del síndrome de Rubinstein y Taybi. Arch Pediatr Esp (Madrid) 1972;30:421-9.

38 Padfield CJ, Partington MW, Simpson NE. The RubinsteinTaybi Syndrome. Arch Dis Childh 1968;43:94-101.

39 Sammartino A, Cerbella R, Lembo G, et al. Syndrome de Rubinstein-Taybi à chéloides multiples. $\mathcal{F}$ Fr Ophtalmol 1986;9:725-9.

40 Santhanakrishnan BR. Case reports-Rubinstein-Taybi syndrome. Indian $\mathcal{F}$ Pediatr 1971;38:276-8.

41 Scorza P, Baroncelli G, Contarini A, et al. Considerazion cliniche e diagnostico-differenziali sulla sindrome di Rubinstein-Taybi alle luce de due novi osservazioni. Clin Pediatr (Bologna) 1974;55:608-33.

42 Nengjie Ge, Crandall BF, Shuler JD, et al. Coloboma associated with Rubinstein-Taybi syndrome. F Pediatr Ophthalmol Strabismus 1995;32:266-8.

43 Anderson JF, Smyth HG. Mental retardation with facial abnormalities, broad thumbs and toes. F Ment Subnorm 1968;14:43-9.

44 Davison CBC, Ellis HL, Kuzemko JA, et al. Mental retardation with facial abnormalities, broad thumbs and toes and unusual dermatoglyphics. Dev Med Child Neurol 1967;9: unusual
45 Galoisy C, Raspiller A. Syndrome de Rubinstein et Taybi et lesions corneennes. Bull Soc Ophtalmol 1973;9/10:961-6.

46 Nadal Abella J, Cubells Riero J. Sindrome de RubinsteinTaybi. Manifestaciones oculares y pediatricas. Arch Soc Esp Oftalmol 1974;34:1121-6.

47 Nelson ME. Keratoglobus in the Rubinstein-Taybi syndrome. Br F Ophthalmol 1989;73:385-7.

48 Volpi U, Ricci B, Mastroiacovo P. Le manifestazioni oculari della sindrome di Rubinstein e Taybi. Bull Oculista 1976;55:53-61.

49 Willems R, Goudsmit R, Loeb H. Syndrome de RubinsteinTaybi: a propos de deux observations. Acta Paediatr Belg 1973;27:406-17.

50 Kajii T, Hagiwara K, Tsukahara M, et al. Monozygotic twins discordant for Rubinstein-Taybi syndrome. $f$ Med Genet 1981;18:312-4

51 Krynski S, Biazzi JMM, Machado OAM. Sindrome de Rubinstein-Taybi. Rev Bras Def Mental 1972;7:47-50.

52 Petri H. Korperliche Missbildungen und Syndromerkrankungen bei angeborenem Glaukom. Monatsschr Kinderheilkd 1966;114:327-30.

53 Sinnette C, Odeku EL. Rubinstein-Taybi Syndrome-the first case in an African child and the first case recognized at birth. Clin Pediatr 1968;7:488-92

54 Ziring PR, Weiss DI, Cooper LZ. The association of congenital glaucoma with the Rubinstein-Taybi syndrome. F Pediatr Ophthalmol 1974;11:203-6.

55 Bardelli AM, Lasorella G, Barberi L, et al. Ocular manifestations in Kniest syndrome, Smith-Lemli-Opitz syndrome, Hallermann-Streiff-Francois syndrome, Rubinstein-Taybi syndrome and median cleft face syndrome. Ophthal Paed Genet 1985;6:103-7.

56 Blanck M-F, Braun-Vallon S, Guillamat ML. Deux cas de nanisme constitutionnel (syndrome de Rubinstein et Taybi) avec glaucome. Bull Soc Ophtalmol Fr 1968;68:173-

57 Buchinger G, Stroder J. Rubinstein-Taybi Syndrom bei wahrscheinlich eineiigen Zwillingen und drei weiteren Kindern. Gleichzeitige Korrektur einer Fehldiagnose. Klin Padiatr 1973;185:296-307.

58 Frézal J, Gabilan J-C, Dommergues J-P, et al. Un nouveau cas de syndrome de Rubinstein-Taybi. Arch Pédiatr 1968;25:116.

59 Levy NS. Juvenile glaucoma in the Rubinstein-Taybi Syndrome. F Pediatr Ophthalmol 1976;13:141-3.

60 Levy-Leblond E, D'Oelsnitz M, Vaillant J-M, et al. Le syndrome de Rubinstein et Taybi. Arch Pédiatr 1969;26:52335.

61 Magli A, Corvino C, Sammartino A. Glaucoma congenito in un caso con sindrome di Rubinstein e Taybi. Bull Ocul 1984;63:49-55.

62 Manzitti E, Lavin JR. Le glaucome congenital dans le syndrome de Rubinstein-Taybi. Ann Oculist (Paris) 1972; 205:1005-12.

63 Manzitti E, Lavin JP, Diaz JP. Signos oftalmologicos del sindrome de Rubinstein-Taybi. Arch Oftalmol (B Aires) 1969; 44:228-30.

64 Militerni R, Balzarano F, Vittozzi C, et al. Sindrome di Rubinstein-Taybi: descrizione di 2 casi. Acta Neurol (Napoli) 1979;39:116-22.

65 Murken AH, Pfeiffer RA. Das Syndrom von Rubinstein und Taybi. Padiatr Padol 1968;4:259-69.

66 Shihab ZM. Pediatric glaucoma in Rubinstein-Taybi syndrome. Glaucoma 1984;6:288-90.

67 Weber U, Bernsmeier H. Rubinstein-Taybi-Syndrom und juveniles Glaukom. Klin Mbl Augenheilk 1983;183:47-9.

68 Verma IC. Rubinstein Taybi syndrome. Indian $\mathcal{f}$ Pediatr 1970;7:672-4.

69 Scherini A, Vegni M. Due casi di sindrome di RubinsteinTaybi. Minerva Pediatr 1977;29:133-7.

70 Schönenberg $\mathrm{H}$, Radermacher EH, Frank M, et al. Phenylketonurie assoziiert mit Rubinstein-Taybi Syndrom, spondylärer Dysplasie, linksseitiger vasculärer Schrump-
fnebenniere. Klin Pädiatr 1977;189:482-9.

71 De Oliveira AJ, Maciel JA, Melo da Silva RJ. Polegares e halux largos, anormalidades faciais e retardo mental (sindrome de Rubinstein-Taybi). $\mathcal{F}$ Pediat (Rio de $\mathfrak{f}$ ) 1974;39:101-5.

72 Bejar RL, Smith GF. Broad thumbs and great toes syndrome: Rubinstein-Taybi syndrome. F Fla Med Assoc 1969;56: $111-14$

73 Bonioli E, Bellini C, Di Stefano A, et al. Dandy-Walker malformation and eye coloboma in a Rubinstein-Taybi phenotype. Am f Hum Genet 1988;43 (suppl):A40.

74 Chmielik J, Wymyslowska D, Winkielman J. Zespol Rubinstein-Taybi w Swietle Problemow Klinicznych. Pediatr Pol 1982;57:1087-92.

75 Falbe-Hansen I. A case of the Rubinstein-Taybi syndrome. Acta Ophthalmol 1968;47:33-8.

76 Goudeau Negrier E. Sindroma de Rubinstein y Taybi. Rev Chil Pediatr 1970;41:446-9.

77 Guion-Almeida ML, Richieri-Costa A. Callosal agenesis, iris coloboma, and megacolon in a Brazilian boy with Rubinstein-Taybi syndrome. Am f Med Genet 1992;43: 929-31.

78 Hennekam RCM, Van Den Boogaard MJ, Sibbles BJ, et al. Rubinstein-Taybi syndrome in the Netherlands. Am $\mathcal{F} \mathrm{Med}$ Genet Suppl 1990;6:17-29.

79 Marin R, Diament J. Sindrome de Rubinstein y Taybi a Propositi de un caso. Arch Pediatr (Uruguay) 1972;43:8493.

80 Ricci B, Falsini B, Lacerra F, et al. Bilateral optic nerve colobomata in Rubinstein-Taybi syndrome. Ann Ottalmol Clin Oculist 1984;110:193-98. 
81 Simmons JD, LaMasters D, Devron C. Computed tomography of ocular colobomas. Am $\mathcal{7}$ Roentgenol 1983;141. graphy

82 Taybi H, Rubinstein JH. Broad thumbs and toes and unusual facial features. Am $\mathcal{F}$ Roentgenol 1965;43:362-6.

83 Yago K. A case of the Rubinstein-Taybi syndrome. Acto Ophthalmol fpn 1973;24:1264-7.

84 Lahlou B, Carrier C. Ménométrorragies et bifidité utérine dans un cas du syndrome du "pouce en spatule" (Rubinstein et Taybi). Rev Int Pédiatr 1971;14:5-14.

85 Louhimo T, Thuneberg P, Waltimo R. Rubinstein-Taybin Syndrooma. Duodecim 1971;87:899-902.

86 Principi N. Su un caso di sindrome di Rubinstein e Taybi. Minerva Pediatr 1966;18:1037-40.

87 Scanabissi F, Neri G. Osservazione su un caso di sindrome di Rubinstein-Taybi. Clin Pediatr 1970;52:495-504.

88 Tamaro P. Sindrome di Rubinstein e Taybi associata ad atrogriposi. Acta Paed Latina 1974;27:161-72.

89 Chlebarov St. Das Rubinstein-Taybi-Syndrom. Päd Prax 1971;10:279-83.

90 Gerbeaux J, Pariente J, Costil J. Un cas de syndrome de Rubinstein-Taybi chez un enfant de cinq mois. Arch Pédiat Rubinstein-Tay
$1968 ; 25: 465$

91 Chikazawa K, Abe F, Nonaka E. The Rubinstein Taybi syndrome with congenital optic pit. Folia Ophthalmol fpn 1978;29:1424-8.

92 Robinson GC, Miller JR, Cook EG, et al. Broad thumbs and toes and mental retardation. Am F Dis Child 1966;3:28790.
93 Maier J, Dagnelie G, Spekreijse H, et al. Principal component analysis for source localisation of VEP's in man. Vision Res 1987;27:165-77.

94 Ossenblok P, Reits D, Spekreijse H. Checksize dependence of the sources of the hemifield-onset evoked potential. Doc Ophthalmol 1994;88:77-88.

95 Spekreijse H, Riemslag FCC. Gross potential recording methods in ophthalmolgy. In: Carpenter RHS, Robson JG, eds. Vision research, a practical guide to laboratory methods. Oxford: Oxford University Press, 1999.

96 Van der Tweel LH, Spekreijse H. Psychophysics and electrophysiology of a rod-achromat. Doc Ophthalmol Proc Series, Xth ISCERG Symposium 1973:163-73.

97 Van der Tweel LH, Auerbach E. Achromatopsia, electrophysiological evidence for separate luminance and contrast processing. Doc Ophthalmol Proc series, XIIIth ISCERG Symposium. The Hague: Dr W Junk, 1977:105-13.

98 Lennerstrand G. Delayed visual evoked cortical potentials in retinal disease. Acta Ophthalmol (Copenh) 1982;60:497504.

99 Pathanasopoulos PG, Papakostopoulos D. Pattern reversal visual evoked potentials in retinitis pigmentosa. Int $\mathcal{f}$ Psychophysiol 1994;16:245-50.

100 Heckenlively JR. Retinitis pigmentosa. Philadelphia: JB Lippincott, 1988

101 Francois J. Metabolic tapetoretinal degenerations. Surv Ophthalmol 1982;26:293-333. 